\title{
The Impact of Fiscal Decentralization on Local Economic Development in East Java
}

\author{
Jumadi*, M. Pudjiharjo*, Ghozali Maski*, Moh. Khusaini* \\ *(Economics, University of Brawijaya, Indonesia)
}

\begin{abstract}
This research aims at investigating and analyzing the impact of implementation of fiscal decentralization on local economic development in East Java. This study uses panel data across districts and cities in East Java Province, which consists of 29 districts and 9 cities in 2007-2010. The data used, including direct expenditures and indirect expenditures, capital expenditures, grants (DAU, DAK and DBH), education index, health index, index of purchasing power, long road, electricity ratio, and economic growth, as well as other data that support this research. This research was conducted by using SEM to identify the effect of fiscal decentralization, human development, physical development and input factors on economic growth. Results of this study indicate that there is a significant and positive effect between Fiscal Decentralization on Human Development; Fiscal Decentralization on Physical Development; Human Development on Local Economic Growth; Physical Development to Local Economic Growth, and Input Factors on Local Economic Growth. In addition, this study also showed a negative effect between Fiscal Decentralization on Local Economic Growth. Keywords: Fiscal Decentralization, Local Economic Development, Human Development, Physical Development, Factor Inputs, Local Economic Growth.
\end{abstract}

\section{Introduction}

Fiscal decentralization is an issue and a major concern for developing countries in the 1990s. Attention to fiscal decentralization was initially motivated by political motives. For example, in the Philippines (Eaton, 2001), Moldova (IMF, 1999), and South Africa (Ahmad, 1998) the emergence of fiscal decentralization because of the insistence of existing multi-party development, in the inter-ethnic strife backed Ethiopia, Mozambique and Uganda in the civil war caused prolonged (Livingstone and Chalton, 2001). Even the appearance of fiscal decentralization in Indonesia is very close with political issues and concerns over national disintegration (Brodjonegoro and Asanuma, 2000 in Khusaini, 2006).

For developing countries, fiscal decentralization is believed to be a solution to all kinds of economic and political problems being faced, however, fiscal decentralization also has potential problems, which are causing new problems that become an additional burden that has endured over the years. In terms of benefits, some experts stressed the need for fiscal decentralization to economic efficiency, cost efficiency in the provision of public goods, improved accountability, transparency, and increased mobility of funds. In terms of losses, other experts say that none of the benefits of fiscal decentralization that can be achieved by countries that preference populated almost impossible accommodated by the government budget, and the institutional capacity of local governments are very low. From this perspective, it looks fiscal decentralization has tended to increase costs, reduce the efficiency of government services, distorts the economy, and may cause more severe imbalances between regions and macroeconomic instability (Prud'homme, 1995).

Those views are in line with the thinking of some researchers who say that decentralization can be used as a way to encourage local economic growth (Oates (1993), Bird (1993) and Gramlich (1993)). They stated that the revenue and expenditure decentralization can improve the efficiency of the public sector, reducing the budget deficit, and boost economic growth. The argument is that decentralization will increase because the economic efficiency of local governments to be better positioned than the national government to make public service delivery because local governments will better know what is required and needed by the community so it will be more efficient. Fiscal decentralization policies designed poorly can also create a stimulus for local governments to perform Dangan spending less responsible and sustainable (Phillips, 1997). Likewise, decentralization would prejudice the government if decentralization policy implemented by way of a hurry without offset readiness of institutions both administrative and bureaucratic aspects of the government apparatus.

From these arguments, the actual impact of fiscal decentralization for a country so dependent on the style of an existing institution or institutions in the governance of the country. While the empirical literature attempted to show that the impact of fiscal decentralization on regional economic growth, quality of governance, and the provision of public goods such as infrastructure and social welfare that can be mirrored by human development depends on two things: first, the strength of the party system at the national level can be seen from 
the power of the factions in the parliament and the life of the party in the parliament, and the second is the level of subordination, ie whether the local executive appointed or elected by the people (Enikolopov and Zhuravskaya, 2007).

Some research on decentralization in Indonesia after nearly ten years of its implementation, shows that decentralization has not been able to bring in a better economic condition, even the view that decentralization appears only a matter of inter-governmental relations without positive effect for local economic growth. It has also been revealed by the World Bank (1997), Martinez and McNab (2001) that decentralization may also have a negative impact on regional economic growth. This could happen if the local government is not able to capture what the needs of local people and local characteristics of each region.

In line with the spirit of decentralization above, one of the provinces that are very interested in the implementation of fiscal decentralization is the province of East Java. East Java has the largest autonomous region in Indonesia. In this regard, it is interesting to examine the impact of fiscal decentralization in the region, in addition to having a lot number of the autonomous region, but also there are some differences between the characteristics of the region and its various problems. In general, one of the main problems faced by the East Java province are still high levels of poverty. In addition, East Java is also faced with the problems of employment and unemployment.

The problem still has not been able to be resolved through economic growth because economic growth is sustained by household consumption expenditure. In addition to these economic problems, problems related to other aspects of human development as indicated by the Human Development Index (HDI) which is still relatively low and always below the national average. Furthermore, the problem of disparity of economic development in East Java is also a major problem faced by East Java since the era of centralization. In fact, his condition deteriorated as the era of decentralization.

Development of performance indicators in East Java on top also reinforced some research that shows that fiscal decentralization in some areas have not been able to bring in economic development conditions better. In fact, there is the view that decentralization in Indonesia only a matter of inter-governmental relations without positive effect for local economic development. However, the impact on the performance of the construction in East Java which is less optimal as fiscal decentralization is still not known with certainty.

Under these conditions, it becomes interesting to study whether the low achievement of such development is more due to the lack of fiscal decentralization goes well or due to other factors. So the implications of fiscal decentralization to local economic development which is characterized by the level of human development, physical development and growth of the local economy will be very relevant and interesting to be researched and studied more in depth.

\section{Research Methods}

In this research approach Structural Equation Model (SEM) was used to determine the effect of fiscal decentralization, human development and Physical Development of the local economic growth. Structural model according to the formulation of the problem can be seen in the following figure.

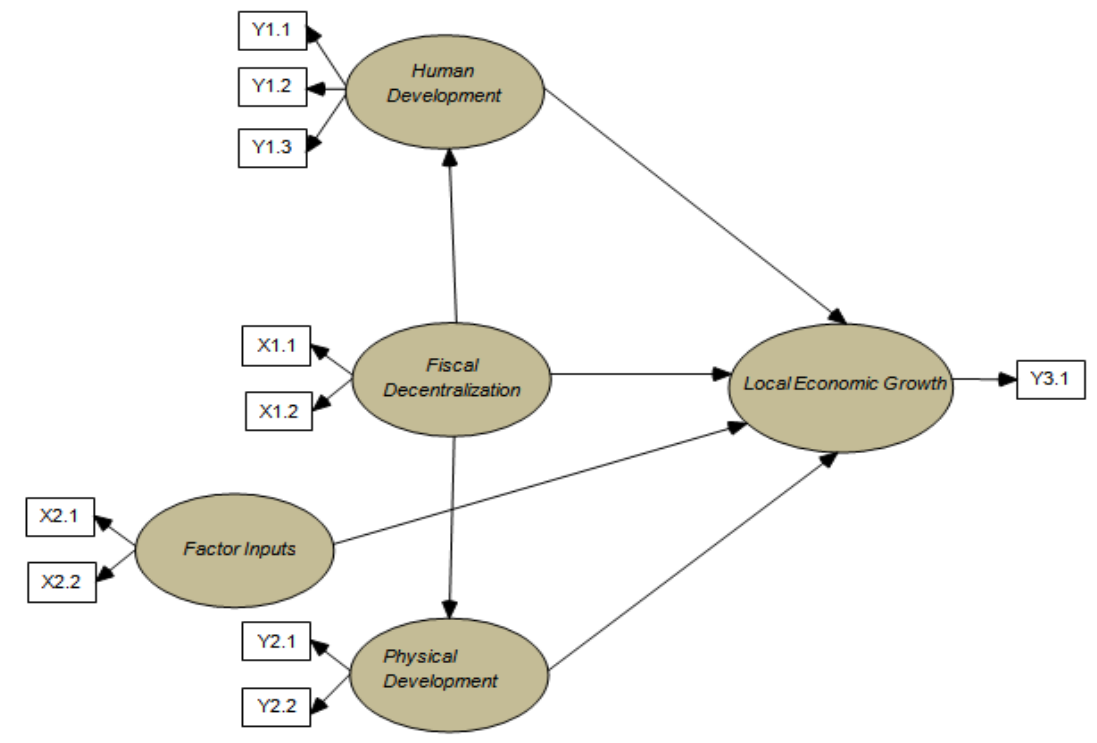

Fig 1. Structural Equation Model Research

Based on the explanation in the previous chapter, the pattern of relationships between variables to be studied is a causal relationship from one or several independent variables to one or more dependent variables. 
Structural Equation Modeling (SEM) is a statistical technique to test a series of relatively complex relationships simultaneously. That relationship can be established between one or more dependent variables with one or several independent variables and can take the form factor or construction, built of several indicator variables. Variables that can take the form of a single variable observed or measured directly (Ferdinand, 2002).

SEM is used to test the research hypothesis. Patterns of relationships between variables that will be examined is the causal relationship of one or more independent variables on one or more dependent variables. In this study there is some form of relationship / equation that will be tested, the influence between Fiscal Decentralization, Human development and Physical Development to the local economic growth. Variables in this study for operational reasons can be defined as follows:

Table 1. Variables And Sub-Variables in Research

\begin{tabular}{|c|c|c|c|}
\hline No & Variable & Sub Variable & Explanation \\
\hline \multirow{2}{*}{1} & \multirow{2}{*}{$\begin{array}{l}\text { Fiscal } \\
\text { Decentralization }\end{array}$} & $\begin{array}{l}\text { Fiscal Decentralization } \\
(\mathrm{X} 11)\end{array}$ & $\begin{array}{l}\text { Ratio of direct expenditure on Fund Balance } \\
\text { (DAU, DAK, DBH) districts / cities every year }\end{array}$ \\
\hline & & $\begin{array}{l}\text { Fiscal Decentralization } \\
(\mathrm{X} 12)\end{array}$ & $\begin{array}{l}\text { Ratio of Indirect Expenses to Fund Balance } \\
\text { (DAU, DAK, DBH) districts / cities every year }\end{array}$ \\
\hline \multirow{2}{*}{2} & \multirow{2}{*}{ Factor Inputs } & Factor Inputs (X21) & Capital Expenditures county / city per year \\
\hline & & Factor Inputs (X22) & Population of the district / city in East Java \\
\hline \multirow{3}{*}{3} & \multirow{3}{*}{$\begin{array}{l}\text { Human } \\
\text { Development }\end{array}$} & $\begin{array}{l}\text { Human Development } \\
\text { (Y11) }\end{array}$ & $\begin{array}{l}\text { Education Index, which is one component of the } \\
\text { HDI is calculated from literacy rates, and } \\
\text { average length of school }\end{array}$ \\
\hline & & $\begin{array}{l}\text { Human Development } \\
\text { (Y12) }\end{array}$ & $\begin{array}{l}\text { Health Index, which is one component of the } \\
\text { HDI is calculated from life expectancy and other } \\
\text { health conditions }\end{array}$ \\
\hline & & $\begin{array}{l}\text { Human Development } \\
\text { (Y13) }\end{array}$ & $\begin{array}{l}\text { Purchasing Power Parity, which is one } \\
\text { component of the HDI is calculated from per } \\
\text { capita public expenditure. }\end{array}$ \\
\hline \multirow{2}{*}{4} & \multirow{2}{*}{$\begin{array}{l}\text { Physical } \\
\text { Development }\end{array}$} & $\begin{array}{l}\text { Physical Development } \\
\text { (Y21) }\end{array}$ & $\begin{array}{l}\text { Proportion of road length in Good Condition, } \\
\text { which is calculated from a good amount of road } \\
\text { length divided by the entire length of the existing } \\
\text { road }\end{array}$ \\
\hline & & $\begin{array}{l}\text { Physical Development } \\
\text { (Y22) }\end{array}$ & $\begin{array}{l}\text { Ratio of availability Power / Ratio Electricity, } \\
\text { which is calculated from the number of } \\
\text { customers divided by the number of electrified } \\
\text { households }\end{array}$ \\
\hline 5 & $\begin{array}{l}\text { Local Economic } \\
\text { Growth }\end{array}$ & $\begin{array}{l}\text { Local Economic } \\
\text { Growth (Y31) }\end{array}$ & Real GDP growth rate of Regency / City \\
\hline
\end{tabular}

\section{Empirical Results}

Of all tests performed, fiscal decentralization have a positive impact on human development and physical development. Then, human development, physical development and factor inputs also have a positive impact on local economic growth. However, fiscal decentralization actually have a negative impact on local economic growth. In detail, the influence of independent variables on dependent variable are as follows.

Table 2. Influence of Independent Variables on Dependent Variable

\begin{tabular}{|c|c|c|c|c|c|}
\hline $\begin{array}{c}\text { Independent } \\
\text { Variable }\end{array}$ & $\begin{array}{c}\text { Dependent } \\
\text { Variable }\end{array}$ & $\begin{array}{c}\text { Coefisien } \\
\text { SEM }\end{array}$ & C.R & $\begin{array}{c}\text { P- } \\
\text { value }\end{array}$ & Result \\
\hline $\begin{array}{c}\text { Fiscal } \\
\text { Decentralization } \\
(\mathrm{X} 1)\end{array}$ & $\begin{array}{c}\text { Human } \\
\text { Development (Y1) }\end{array}$ & 0.611 & 5.752 & $0.001^{*}$ & $(+)$ \\
\hline $\begin{array}{c}\text { Fiscal } \\
\text { Decentralization } \\
\text { (X1) }\end{array}$ & $\begin{array}{c}\text { Physical } \\
\text { Development (Y2) }\end{array}$ & 0.750 & 8.075 & $0.001^{*}$ & $(+)$ \\
\hline $\begin{array}{c}\text { Human } \\
\text { Development (Y1) }\end{array}$ & $\begin{array}{c}\text { Local Economic } \\
\text { Growth (Y3) }\end{array}$ & 0.547 & 3.576 & $0.001^{*}$ & $(+)$ \\
\hline $\begin{array}{c}\text { Physical } \\
\text { Development (Y2) }\end{array}$ & $\begin{array}{c}\text { Local Economic } \\
\text { Growth (Y3) }\end{array}$ & 0.254 & 2.166 & $0.030^{*}$ & $(+)$ \\
\hline Factor Inputs (X2) & $\begin{array}{c}\text { Local Economic } \\
\text { Growth (Y3) }\end{array}$ & 0.530 & 4.721 & $0.001^{*}$ & $(+)$ \\
\hline $\begin{array}{c}\text { Fiscal } \\
\text { Decentralization } \\
(X 1)\end{array}$ & $\begin{array}{c}\text { Local Economic } \\
\text { Growth (Y3) }\end{array}$ & -0.027 & -0.205 & 0.837 & $(-)$ \\
\hline
\end{tabular}

Note: $*$ Significant at $5 \%$ level, $t$ value table $(=5 \%)=1.98$

From the above tests, the results obtained are as follows: 


\section{Fiscal Decentralization Have a Positive Impact on Human Development}

Ideal conditions and are expected when higher per capita education spending matters, high per capita health care, the education index and life expectancy is high. Correlation, when the budget allocated for education spending and higher public health, the community access to education and health services will be easier. This is expected to result in increased education index and life expectancy index. This condition is consistent with the results of research that has been done by Rajkumar and Swaroop (2007), which states that public spending on health reduce child mortality (mortality) in some countries with good governance. In addition, public spending on primary education to be more effective in improving achievement in basic education of good governance as well. In general, public spending virtually no impact on health and education outcomes in countries with poor governance.

\section{Fiscal Decentralization Have a Positive Impact on Physical Development}

Physical Development (Physical Development) is a tool needed by the community to support economic activity. Physical development in the region, particularly for public utilities derived from the government budget (budget). The higher the budget allocated for the physical construction of public facilities (infrastructure), the higher the mobility of the people that happen. In effect, in the current economic trade will be increasingly more smoothly, as well as its scope will be broader. While in non-economic areas, increased physical development will increase social capital in the community, particularly in the expansion of the network. This is according to research conducted by Chowdhury et al (2009) which states that decentralization changed the availability of local public infrastructure. The findings are based on calculations that have been done that every district (county / city) are at different investment. Investments made of course based on the condition of the area. In addition to the availability of infrastructure is also based on the needs of local communities, one of which includes the economic activity undertaken. thus, the more economic activity, the availability of public infrastructure will increase. Decentralization will create sustainable development if local governments focus on building regional and equal results. The central government should also support greater decentralization efforts to local governments, not only improve the physical development but also non-physical such as human development. Because human development will bring increased capacity of local governments to the central government to local belief in decentralizing will be realized.

\section{Human Development, a Positive Impact on Local Economic Growth}

These results indicate that there is a significant and positive effect of fiscal decentralization on Local Economic Growth. The high value of the human development index will affect human development. High health index, indicating a good quality of public health. Under these conditions, the expected productivity will increase, thereby increasing regional economic growth. This is according to research conducted by Bloom et.al (2004) which states that the level of good health will play a major, positive, and significant impact on aggregate output. Life expectancy also have an impact on growth, which will also influence the effect of worker productivity. These results are in accordance with the fact that most areas in East Java, where when a low health index performance (below average), the economic growth rate is also low anyway (below average). As happened in some areas in Madura and some surrounding areas such as the regency, Situbondo, Jember, Lumajang, and Pasuruan.

\section{Physical Development of a Positive Impact on Local Economic Growth}

There is a significant and positive influence Physical Development for Local Economic Growth. The better the physical condition of development will increasingly run the economy in a region. Physical Development in this study is characterized by the proportion of road length in good condition and electricity ratio or the ratio of electrical power availability. The longer the better road conditions expected mobility society in economic activity has increased, thereby increasing regional economic growth. While the ratio of the greater availability of electric power is expected to play a role in the greater society economy movements problems. Infrastructure development is needed in order to promote higher economic growth. Economic growth and infrastructure development that shows a pattern of inter-related. Infrastructure development does not directly affect economic growth, but rather to encourage increased investment. Therefore, an increase in infrastructure development to areas with low economic growth is expected to be a stimulus for increased investment in areas that will impact economic growth.

Overall for the case in East Java can be said that the availability of electricity in a region can affect regional economic growth. This is in line with research Ma'mun and Rahayu (2007) which revealed some results of empirical studies conducted some energy economists associated with the relationship between electricity consumption with the growth of national output; include Ramcharran studies (1990) for the country of Jamaica, Huang (1993) for Chinese state, and Mashi (1996) against a number of countries simultaneously. Even studies conducted Yang (2000) in Ma'mun and Rahayu (2007) showed a two-way relationship between two variables. 
This gives the meaning of a relationship of mutual influence between variable electricity consumption to economic growth. On the one hand, electricity consumption will boost economic activity, so as to affect the level of output of a country, and on the other hand the output growth will boost demand for electric energy.

Results of this study raised the argument Oates (1993) and Martinez-Vazquez and McNab (1997) who argued that spending on infrastructure and social sector will be effective in promoting economic growth of a region. It is also similar to the results of research in Garmendia Prud'homme, et al (2004) who proposed the existence of a positive relationship between the supply of infrastructure and economic growth.

\section{Input Factors Have a Positive Impact on Local Economic Growth}

With the quality of infrastructure, the mobilization activity and economic activity can be run properly and smoothly. This is consistent with research conducted by Lofgren and Robinson (2004) which shows that government spending on infrastructure has a significant effect on economic growth.

High population with high economic growth and vice versa is a reasonable condition. But if the high number of residents with low economic growth and vice versa is an exception condition. As stated by Sadono Sukirno (2006:430) that the population increased from time to time may be driving or inhibiting the economic growth. Population increase will increase the amount of labor, and the addition will allow the country to increase production. Besides, keep in mind also, that employers are part of the population. Then the extent of economic activity undertaken by a nation also depends on the number of entrepreneurs in the economy. If the availability of entrepreneurs in a particular population is more, it will be more economic activities are carried out.

The total population, followed by an increase in population can affect the quality of economic growth. This is in line with research Jones (1995) in a study of the test time series on the endogenous growth model argue that the rate of population growth is a determinant of economic growth. in his research, Jones (1995) suggested that the high economic growth in the past due to high population growth. The same view was also expressed by Rajagukguk (2010) that if the economic growth rate is proportional to the rate of population growth, the population growth in Indonesia has a positive effect on economic growth. According Rajagukguk (2010), a view that emerged during this time was negative population growth compared with the growth of the economy, it is actually wrong. Because there are other indications, that is associated with school-age children who later worked. With so quite reasonable, if the results of this study population had a positive relationship with economic growth. Although these findings are contrary to the basic theory is that it was built for a population of a negative effect on economic growth (Barro and Sala-i-Martin, 1994).

\section{Effect of Fiscal Decentralization Against Local Economic Growth}

Results of this study indicate that there is a negative effect and not significant of fiscal decentralization on economic growth locally. This suggests that the role of government will have very little effect on the success of local economic growth. The role of government in this case a budget policies issued to improve economic growth in the region. Local economic growth has a very broad sense, not just to raise GDP per year in a region, but also the activities undertaken by the regions to develop economic activity and living standards.

Fiscal decentralization can be measured by how much the ratio of direct expenditures and indirect expenditures of the fund balance as DAU, DAK, and DBH in an area. Hopefully, the high ratio of direct and indirect spending to balance funds will greatly affect the economic growth of the region. However, these results are not in accordance with the desired expectations. High and low ratio of direct and indirect spending has no effect on regional economic growth. This condition can occur due to several reasons such as that proposed by Akai, et al (2007) that the relationship of fiscal decentralization on economic growth is hump-shaped. By the time the degree of fiscal decentralization is still low, then an increase in fiscal decentralization will provide a positive and significant impact, both on the revenue indicators and indicators of expenditure. But when fiscal decentralization is optimal, an increase in the degree of fiscal decentralization will lead to negative economic perrtumbuhan. In this study, the relationship of fiscal decentralization was also negative, but because of the relationship between the two is not significant, so it can not be said that fiscal decentralization has a negative influence on economic growth.

Results of this study also support the results of research conducted by Woller and Phillips (1998) who provide evidence that there is no significant relationship between fiscal decentralization and economic growth. in addition, this study also reinforces the research that has been conducted by Tarin (2003) which suggests that fiscal decentralization has a negative effect on the growth of real GDP per capita, but not significantly.

Furthermore, these results also indicate that fiscal decentralization creates inefficiencies in public service. This condition is contrary to the argument that local governments tend to be closer to the people so as to provide more efficient public services (Oates, 1972). However, according to Tarin (2003) that fiscal decentralization does not jeopardize macroeconomic stability. 
This study also nearing the result of research conducted by Davoodi and Zou (1998) who argued that the relationship between economic growth and fiscal decentralization is negative in the case of developing countries, while developed countries are not significant. In addition, this study also supports the results of research conducted by Zhang and Zou (1998) on fiscal decentralization in China, the negative impact on regional economic growth.

According to the World Bank (1997b), fiscal decentralization may affect economic growth indirectly. There are three mechanisms of the effect of fiscal decentralization on economic growth. The first argument, saying that fiscal decentralization will improve economic efficiency in public spending, which will encourage a dynamic effect on economic growth. Therefore, there is a positive effect of fiscal decentralization on economic growth. The second argument, the possibility of decentralization will lead to macroeconomic instability that this will impact on the economic growth, so in this case decentralization can have a negative impact on economic growth. The third argument, stating that developing countries have the economic and institutional environment that is different from developed countries. This makes a lot of developing countries in many cases it does not benefit from fiscal decentralization. In addition, the institutions in developing countries do not provide incentives for local governments to take advantage of information obtained from the fiscal decentralization policy, because in most cases the local leaders was appointed and not elected directly by the people. The issue of lack of human resources in the area may also lead to the success of a country's fiscal desetralisasi.

Additionally, Prud'homme (1995) also suggests some of the problems that cause the failure of fiscal decentralization in promoting economic growth, among others: (i) the local government can not meet the preferences of the local community, both because of the lack of political will, or caused by the apparatus or less motivated and qualified to carry out these responsibilities, (ii) increasing corruption at the local level because local politicians and bureaucrats are generally more vulnerable because it is easily accessible by groups that have an interest. Therefore, if the local government is able to eliminate or reduce corruption at the local level, the fiscal decentralization will create allocative efficiency and economic growth, (iii) the political system is not democratic; thus the basic premise that local governments have stronger incentives to provide goods Local public more efficiently may not apply (Tanzi, 1996). In a democratic system of government that is not actually there is a view that assumes that fiscal decentralization simply as a tool used by local governments to exploit local and national resources. If the local government can eliminate a variety of factors such inhibitors, the greater the success of fiscal decentralization in the public welfare in the region.

Not influential fiscal decentralization to local economic growth for East Java case in this study did not directly, more fiscal decentralization significantly affect the performance of human development and physical development, which further physical development and human development meant significantly affect the growth of the local economy. It is also unrealistic because the capacity of government spending compared to the capacity of the private sector is relatively very small. Therefore the government's budget policy synchronization relatively small amount in question must effectively stimulate economic growth through non-budgetary synchronization framework (regulation).

\section{Conclusion}

Implementation of fiscal decentralization benefit regional development in the district / cities in East Java, this is indicated by:

1. Increasing the quality of human resources of both aspects of education index, health index and the index of purchasing power.

2. Increasing the quality of infrastructure

3. Accelerate economic growth by improving the quality of human development and quality of infrastructure.

Then, there are indications of differences in the effectiveness of the implementation of decentralization across districts / cities and indications that the private sector's role is dominant in economic growth in East Java.

References

[1] Akai, Nobuo, et all, Complementarity, Fiscal Decentralization and Economic Growth, Economics of Governance, Heidelberg, 8 (4), 2007, 339 .

[2] Barro. Robert J and Sala-i-Martin. Economic Growth (Cambridge, MIT Press, 1995).

[3] Baskaran. Thushyanthan., and Feld Lars P. Fiscal Decentralization and Economic Growth in OECD Countries: Is There a Relationship?, CESifo Workifo Paper, 2009, 2721.

[4] Bird, R. M, Threading the Fiscal Labyrinth: Some Issues in Fiscal Decentralization, National Tax Journal, 46 (3), $1993,207-227$.

[5] Bloom, David E, David Canning and Jaypee Sevilla, The Effect of Health on Economic Growth: A Production Function Approach. Elsevier Ltd: World Development, 32 (1), 2004, 1-13.

[6] Chowdhury, Shyamal et, all, Governance Decentralization and Local Infrastructure Provision in Indonesia. International Food Policy Research Institute, 2009, IFPRI Discussion Paper 00902.

[7] Davoodi, Hamid, and Heng-fu Zou.. Fiscal Decentralization and Economic Growth: A Cross Country Study. Journal of urban Economics, vol 43, 1998.

[8] Eaton, K, Political Obstacles to Decentralization: Evidence from Argentina and the Philippines, Development and Change, vol. 32, 2001, 101-127. 


\section{The Impact Of Fiscal Decentralization On Local Economic Development In East Java}

[9] Enikolopov. Ruben and Ekaterina Zhuravskaya. Decentralization and Political Institutions. Journal of Public Economics vol 91, 2007, 2261-2290.

[10] Ferdinand, Augusty. Structural Equation Modelling Dalam Penelitian Manajemen. Edisi 2 Seri Pustaka Kunci 03. (Semarang, BP UNDIP, 2002).

[11] Garmendia, Briceno, Cecilia, Estache, Antonio and Shafik, Nemat, Infrastructure Services in Developing Countries: Access, Quality, Costs, and Policy Reform, World Bank Policy Research Paper, 2004, 3468.

[12] Gramlich, E, A Policy Maker's Guide to Fiscal Decentralization, National Tax Journal, 46, 1993, 229-235.

[13] IMF, Republic of Moldova: Recent Economic Developments, IMF Staff Country Report, 99/110, 1999.

[14] Jones, Charles I, Time Series Test of Endogenous Growth Models, The Quarterly Journal of Economics, 110 (2), $1995,495-525$.

[15] Khusaini, Mohammad, Ekonomi Publik Desentralisasi Fiskal dan Pembangunan Daerah (Malang, BPFE UNIBRAW, 2006).

[16] Litvack Jennie, Junaid Ahmad and Richard Bird, Rethinking Decentralization in Developing Countries (Washington, D.C, World Bank Institute, 1998).

[17] Livingstone, I., and R. Charlton. Financing Decentralized Development in a Low-Income Country: Raising revenue for local government in Uganda, Development and Change, 32(1), 2001, 77-100.

[18] Lofgren, Hans and Sherman Robinson. Public Spending, Growth and Poverty Alleviation in Sub-Saharan Africa: A Dynamic General Equilibrium Analysis, Paper prepared for presentation at the Seventh Annual Conference on Global Economic Analysis, Trade, Poverty, and the Environment, organized by the World Bank and the Center for Global Trade Analysis and held at The World Bank headquarters, Washington, D.C, 2004.

[19] Makmun and Sri Lestari Rahayu, Permasalahan Bidang Ketenagalistrikan Sekarang dan Masa Depan (Fokusmedia, Bandung, 2007)

[20] Martinez-Vazquez, Jorge and Robert M. McNab, Fiscal Decentralization and Economic Growth, International Studies Program, Andre Young School of Policy Studies. Georgia State University. Working Paper, 01, 2001

[21] Martinez-Vazquez, Jorge. M and McNab, R, Fiscal Decentralization, Economic Growth, and Democratic Governance, Working Paper, 1997, 1-41.

[22] Oates, W, Fiscal Decentralization and Economic Development, National Tax Journal, 46, 1993, $237-243$.

[23] Oates, Wallace. E, Fiscal Federalism (New York, Harcourt Brace Jovanovich, 1972)

[24] Phillips, K. L. and Gary Woller, Does Fiscal Decentralization Lead to Economic Growth?, Brigham Young University, 1997.

[25] Prud'homme, Remy, On The Danger of Decentralization, The World Bank, Policy Research Working Paper, 1995, 1252.

[26] Rajagukguk, Wilson, Pertumbuhan Penduduk sebagai Faktor Endogen dalam Pertumbuhan Ekonomi Indonesia, doctoral diss., Universitas Indonesia, Jakarta, 2010.

[27] Rajkumar, Andrew Sunil and Swaroop, Vinaya, Public Spending And Outcomes: Does Governance Matter?, ELSEVIER: Journal of Development Economics, 86, 2008, 96-111.

[28] Sukirno, Sadono, Pengantar Teori Makro (Jakarta, PT. Raja Grafindo Persada, 1985).

[29] Tanzi, Vito, Fiscal Federalism and Decentralization: A Review of Some Efficiency and Macroeconomics Aspects, Annual Bank Conference on Development Economics, 1996, 295-316

[30] Tarigan, M. Syamsul, Fiscal Decentralization and Economic Development: A Cross-Country Empirical Study, Forum of International Development Studies, 24, 2003, 245-271.

[31] Woller, Gary M., and Philips, Kerk, Fiscal Decentralization and LDC Economic Growth: An Empirical Investigation. The Journal of Development Studies, 34 (4), 1998.

[32] World Bank, On Line Source Book on Decentralization and Rural Development, Decentralization Thematic Team, SDA, 1997b 